\title{
COVID-19 E O LUTO DE PAPÉIS: O ENCONTRO COM O PAPEL DE SOBREVIVENTE
}

\author{
Gabriela Pereira Vidal \\ Amanda Castro \\ DOI: http://dx.doi.org/10.18616/intcov07
}

Um momento de pandemia e as situações ocasionadas por ela, como o isolamento social, podem gerar complicações relacionadas à saúde mental, como o agravamento de patologias já existentes ou surgimento de outras. Entre essas complicações está o luto. Strauch (2017, p. 50) descreve que “[...] o luto é uma reação natural à privação do convívio de alguém ou de algo significativo". Assim, este é relacionado as perdas de forma geral, inclusive, perdas de papéis. De acordo com Moreno (1993, p. 27), “[...] o papel é a forma de funcionamento que o indivíduo assume no momento específico em que reage a uma situação específica, na qual outras pessoas ou objetos estão envolvidos". Por meio desse conceito, pode-se perceber os diversos papéis que um sujeito desempenha em seu cotidiano, entre eles: pai ou mãe, filho/a, esposo/a, trabalhador/a, estudante, entre outros.

Correlacionando a teoria psicodramática, o luto e a covid-19, são 
proteção do público de risco; o uso de máscaras e outros utensílios de proteção e cuidado em diversos dos nossos papéis, são alguns exemplos.

Diante desses lutos de papéis, o que resta ao sujeito, talvez, seja o descrito por Strauch (2017): acolher suas angústias, fortalecer os papéis que ficaram, revisitar com carinho lembranças pré-pandemia. Viver e aceitar a ausência de controle durante a pandemia e no pós-pandemia, permitir-se realizar simbolicamente momentos e rituais de conclusão não possíveis durante o isolamento e ressignificar essas perdas para se abrir a novos e diferentes papéis.

Conclui-se que, em meio as perdas, uma forma de manter a saúde mental em tempos de pandemia, talvez possa ser buscar reconhecer-se em novos papéis. Identificando o novo cenário, experimentando novas respostas, aceitando o caráter de incontrolabilidade e encontrando o papel de sobrevivente.

\section{REFERÊNCIAS}

MORENO, Jacob Levy. Psicodrama. Tradução de Álvaro Cabral. São Paulo: Cultrix, 1993.

STRAUCH, Vanessa Ramalho Ferreira. Ressignificação da morte na abordagem psicodramática: perdas e ganhos no luto. Rev. bras. Psicodrama, São Paulo, v. 25, n. 1, p. 59-67, jun. 2017. Disponível em: http://dx.doi.org/15329/23180498.20170006. Acesso em: 8 dez. 2020. 